\title{
Ellen Rehm. « Persica in Monachia. Objekte aus der Achämenidenzeit in der Archäologischen Staatssammlung München »
}

\section{Astrid Nunn}

\author{
(2) OpenEdition \\ Journals \\ Édition électronique \\ URL : http://journals.openedition.org/abstractairanica/42611 \\ DOI : 10.4000/abstractairanica.42611 \\ ISBN : 1961-960X \\ ISSN : 1961-960X \\ Éditeur : \\ CNRS (UMR 7528 Mondes iraniens et indiens), Éditions de l'IFRI
}

Référence électronique

Astrid Nunn, «Ellen Rehm. «Persica in Monachia. Objekte aus der Achämenidenzeit in der

Archäologischen Staatssammlung München » », Abstracta Iranica [En ligne], Volume 37-38-39 | 2018, document 18, mis en ligne le 10 mars 2018, consulté le 10 décembre 2020. URL : http://

journals.openedition.org/abstractairanica/42611; DOI : https://doi.org/10.4000/abstractairanica 42611

Ce document a été généré automatiquement le 10 décembre 2020.

Tous droits réservés 


\title{
Ellen Rehm. « Persica in Monachia. Objekte aus der Achämenidenzeit in der Archäologischen Staatssammlung München »
}

\author{
Astrid Nunn
}

\section{RÉFÉRENCE}

Ellen Rehm. « Persica in Monachia. Objekte aus der Achämenidenzeit in der Archäologischen Staatssammlung München ». Studia Mesopotamica. Jahrbuch für altorientalische Geschichte und Kultur 1, 2014, p. 333-367.

1 Le musée archéologique de Munich, spécialisé dans l'histoire de la Bavière de la Préhistoire au Moyen Âge, possède néanmoins quelques 4000 objets des civilisations du Proche Orient ancien. Une centaine d'entre eux appartiennent à l'époque achéménide. Le plus grand groupe consiste en bijoux - boucles d'oreille, torques et perles - de provenance libanaise. Les bijoux sont en argent, mais des traces d'or montrent qu'ils étaient recouverts d'une dorure au mercure. Un bracelet rigide, dont les extrémités sont ornées de têtes de veau consiste en un alliage d'argent et de mercure, confirme ainsi les recherches antérieures de l'A. selon lesquelles les bracelets à têtes de veau sont en argent et non en or. Les éléments d'une kliné peuvent être assemblés selon le modèle découvert dans une tombe de Tell el-Farah. Quelques pointes de flèches sont perses. Enfin trois cavaliers en terre cuite de « Syrie » appartiennent au type du cavalier perse. Deux d'entre eux portent un objet arrondi qu'il est encore difficile d'identifier. 


\section{AUTEURS}

\section{ASTRID NUNN}

Université de Munich 